NBER WORKING PAPER SERIES

\title{
STRENGTHENING EMPLOYMENT-BASED PENSIONS IN JAPAN
}

\author{
Robert L. Clark \\ Olivia S. Mitchell \\ Working Paper 8891 \\ http://www.nber.org/papers/w8891 \\ NATIONAL BUREAU OF ECONOMIC RESEARCH \\ 1050 Massachusetts Avenue \\ Cambridge, MA 02138 \\ April 2002
}

The authors are grateful for financial support for this research from the Economic and Social Research Institute and the National Bureau of Economic Research. Without implicating them, we have benefited from discussions with many experts, most recently Harald Conrad, Tatsuo Hatta, Charles Yuji Horioka, Milton Isa, Su mio Morita, Shinichi Nishiyama, Naohiro Ogawa, Junichi Sakamoto, Atsushi Seike, Kenji Sekine, William Shipman, Noriyuki Takayama, Masaharu Usuki, and Bill Wilder. Any errors and all opinions remain the authors' own. This study is part of the NBER program on the Economics of Aging. The views expressed herein are those of the authors and not necessarily those of the National Bureau of Economic Research.

(C) 2002 by Robert L. Clark and Olivia S. Mitchell. All rights reserved. Short sections of text, not to exceed two paragraphs, may be quoted without explicit permission provided that full credit, including $(\mathrm{C}$ notice, is given to the source. 
Strengthening Employment-Based Pensions in Japan

Robert L. Clark and Olivia S. Mitchell

NBER Working Paper No. 8891

April 2002

JEL No. G2, H, J3

\begin{abstract}
We investigate how the Japanese pension market for funded employment-based pensions is changing and how it might be strengthened in order to better serve one of the most rapidly aging populations in the world. Public and private pensions in Japan are estimated to hold around US\$3 trillion, making that system the second largest globally after the United States. However, unfavorable economic developments have cut sharply cut into asset values, and the weak economy is undermining traditional lifetime employment contracts. Recent legislation permitting the establishment of defined contribution plans in Japan may provide new employer-sponsored retirement plan opportunities. We first describe the Japanese pension system at the end of the 20th century and provide an overview and evaluation of the changes in the pension arena emerging from the 2001 legislation. Next we show that important design questions remain to be answered, if Japanese employment-based pensions are to be reformed and modernized. Finally we indicate lessons gleaned from recent changes in US pension plans.
\end{abstract}

Robert L. Clark

College of Management, Box 7229

North Carolina State University

Raleigh, NC 27695

robert_clark@ncsu.edu
Olivia S. Mitchell

The Wharton School

3641 Locust Walk, Rm. 304 CPC

Philadelphia, PA 19104-6218

and NBER

mitchelo@wharton.upenn.edu 


\section{Strengthening Employment-Based Pensions in Japan}

Robert Clark and Olivia S Mitchell

The Japanese population is aging more rapidly than any other, and very low fertility rates going forward mean that this nation's population will start shrinking within the next few years. ${ }^{1} \quad$ International retirement system experts would do well to examine developments in Japanese retirement policies, so as to assess how employer-sponsored pensions fare in such a rapidly aging society. Demographic change in Japan also places pressure on plan sponsors to efficiently manage pension funds and to offer costeffective pensions that workers value. Government policymakers must monitor and revise national pension systems and develop appropriate regulations and tax policies for employer pension plans. Coordination of public and private retirement programs will be essential in the coming decades.

Two important questions are addressed in the present analysis: how is the Japanese pension market for funded employment-based pensions evolving, and what additional steps are needed to strengthen public and private retirement plans? The Japanese pension system is one of the largest in the world, second only to that of the United States pension market. Institutional public and employer pension assets in Japan have been estimated to be around US\$3 trillion (Conrad 2001; Cerulli 1999), of which some US\$0.6 trillion are in private plans (Sakamoto, 2001). But economic news has not been favorable for Japanese pension plans of late. Financial stagnation has sharply reduced asset values, lowered returns on bonds and other fixed income assets, and raised unemployment rates. ${ }^{2}$ In addition, the weak economy

\footnotetext{
${ }^{1}$ Japan is currently the most rapidly aging country in the world. This aging reflects a very low total fertility rate of approximately 1.3, and high life expectancy of 77 years for men and 84 years for women. Projections indicate that the proportion of the population aged 65 and older will increase from about 15\% in 1995 to $27 \%$ by 2025 and the absolute size of the Japanese population will begin to decline in the five years (Ministry of Health, Labor, and Welfare, 1999; Miyatake, 2000).

${ }^{2}$ For exa mple, the index of the stock market (Nikkei 225 stock index) fell from just under 40,000 in the late 1980s to around 15,000 during the 1990s. The unemployment rate rose from $2 \%$ at the beginning of the $1990 \mathrm{~s}$ to $5.3 \%$ in September 2001. In addition, average land prices in Tokyo plummeted during this period and interest rates hover near zero.
} 
is undermining firms' commitment to traditional lifetime employment contracts as deferred compensation promises (Seike, 1997).

To modernize the pension environment in Japan, a number of regulatory changes were recently passed. These changes, intended to restructure and provide new opportunities for employer-sponsored retirement plans, followed closely on the heels of modifications in the Japanese pay-as-you-go social security system which is made up by the Employees' Pension Insurance and the National Pension, described in more detail below. Furthermore, publicly traded firms in Japan must now comply with new and more transparent accounting standards. These standards will also shape pension restructuring, as firms are required to provide new information regarding retirement plan liabilities and assets. To permit an assessment of these patterns, we begin with a review of the status of the Japanese pension system at the end of the twentieth century. Our analysis considers changes in both public and private pension plans and how these programs are interrelated. Next, we turn to a summary and evaluation of the major changes in the employer-provided pension arena emerging from the 2001 legislation. We show that several important unanswered design questions still remain before Japanese employment-based pensions can be effectively modernized. Additional regulations will be required before recently enacted reforms will fully achieve the objective of enhancing retirement security. We also discuss some of the lessons that might be gleaned from recent changes in pension plans in the United States.

\section{The Japanese Pension System at the End of the Twentieth Century}

There are about 67 million economically active persons in Japan. Virtually all workers are included in the national social security system. In addition, about 39 million of these workers are covered by some form of employer-sponsored pension plan (Miyatake, 2000). This section explores how the Japanese retirement system works and outlines the major changes in Japanese retirement policy over the recent past. We trace potential employer as well as employee responses within the context of the current economic situation, population aging and broader 
changes in human resource policies in Japan. Employer pensions are developed within the framework of social security rules and benefits. Changes in mandatory benefit programs, such as lower replacement rates and higher retirement ages, will influence employer and employee preferences concerning private retirement plans. Thus, our analysis begins with a review of the continuing evolution of social security in Japan.

\section{A. An Overview of the Japanese Publicly-Provided Retirement Program}

The Japanese national social security system is composed of two parts, both of which are mainly financed on a pay-as-you-basis (see Figure 1). The first pillar is the National Pension (NP), which provides a flat benefit to all persons who contribute to the system. ${ }^{3}$ The NP was established in 1959 to provide benefits to self-employed workers, farmers, their dependent spouses, the unemployed, and students. These groups are required to make monthly contributions to the NP (¥13,300 per month in 1999; US\$111). ${ }^{4} \quad$ Since 1986, employed individuals and their spouses participate in the NP system through their own and their employer's mandatory contributions to the Employees' Pension Insurance (EPI). Each year, the EPI system transfers to the NP account sufficient funds to pay for the flat benefit of covered employees and their spouses. ${ }^{5}$ The NP flat benefit is equal to a specified quantity of yen per month, multiplied by the number of "covered" months (how long the worker contributed to the system). In 1999, a retiree with full benefit from the NP would receive a monthly benefit of $¥ 67,017$ (US\$558). Prior to the 1986 reform, the full NP benefit was payable at age 65 after 25 years of service; reduced benefits could also be taken as early as age 60 , and the benefit amount could be increased if the worker

\footnotetext{
${ }^{3}$ Prior to 1986, the National Pension covered only persons who were not included in the Employees' Pension Insurance system. Reforms introduced in 1986 expanded the NP to include participants in the EPI, and in essence, the NP became a universal retirement program (Ministry of Health, Labor, and Welfare, 1999).

${ }^{4}$ Throughout this paper, yen figures are converted to US dollars in 2001 at a rate of US\$1=¥ 120 .

${ }^{5}$ The amount of monies transferred by the EPI is determined every year by the number of insured employees paying into the EPI (aged 20 to 59 years) and the number of their dependent spouses (aged 20 to 59 years).
} 
delayed acceptance until age 70 (Clark, 1991). ${ }^{6}$ These benefits are indexed to the cost of living after retirement. The 1986 reforms made a full benefit conditional on 40 years of contributions.

\section{Figure 1 here}

The second pillar of the Japanese public pension system takes the form of an earnings-related defined benefit plan called the Employees' Pension Insurance (EPI) program. The EPI was established in 1941 to cover employed persons. Prior to 1986, the EPI benefit formula was $1.0 \%$ of pay per year of service, linked after retirement to the cost of living index. Subsequently, the benefit formula has been reduced to 0.75 times average indexed (or revalued) earnings, not including bonuses, times the number of covered years. The reduction in the benefit formula was to be phased in over 20 years and the new lower level will apply to all persons born in 1946 or thereafter, reflecting the larger number of covered working years of younger cohorts. Currently, the tax rate used to finance the EPI is $17.35 \%$ of covered earnings, divided equally between the employer and the employee. This contribution is used to finance the flat NP benefit for the worker and his/her spouse plus the earnings-related EPI benefit described above.

Using the current benefit formula, a worker with 40 years of coverage would receive an earningsrelated benefit of $30 \%$ of average real earnings. The flat benefit for a married worker and spouse provides a total replacement rate of over $50 \%$ for most retirees. For example, consider a retired employee with average earnings (approximately $¥ 340,000$ or US $\$ 2,833$ per month) who had 40 years of coverage and whose spouse was a full-time housewife. This couple would receive a flat benefit of $¥ 67,017$ (US\$558) per month for both the husband and the wife, or a total basic benefit of $¥ 134,000$ (US\$1,117) per month. In addition, the retiree would receive $¥ 104,000$ (US\$866) per month from the earnings-related EPI benefit. Thus, the combined publicly supported benefit for the family would be about $¥ 238,000$ (or US\$1,983; Miyatake, 2000). Reforms implemented in 1994 gradually boosted the eligibility age for the NP flat benefit from age 60 to 65; however, eligibility for EPI benefits was maintained at age 60 throughout the 1990s.

\footnotetext{
${ }^{6}$ Benefits taken at age 60 are $70 \%$ of the age 65 benefit. If the initial acceptance of benefits is delayed until age 70 , the benefit is $142 \%$ of the age 65 benefit (Sakamoto, 2001b).
} 
If those benefit promises had been maintained in the face of Japan's rapid pace of aging, additional tax revenue would have been required to cover promises made under NP and EPI rules (Ministry of Health, Labor, and Welfare, 1999). For instance, government review groups projected that EPI tax rates would have to increase from $17.35 \%$ to $34.5 \%$ of covered earnings by 2025 , and contributions to the NP were projected to have to rise by about $100 \%$. As a result, a comprehensive review of benefit formulas, eligibility conditions, retirement ages, and financing options was conducted, resulting in the reform law of 2000 .

One key aspect of the 2000 public pension reforms was that they cut future social security benefits in various ways. First, the EPI benefit formula was further curtailed by about $5 \%$, from 0.75 to $0.7125 \%$ per year of service. Second, the indexation of EPI and NP retirement benefits for beneficiaries ages 65 and older was switched from wage indexation to price indexation. Third, for future workers, the normal retirement age for the EPI pension was raised from 60 to 65 for both men and women. These changes will be gradually phased in over time for new retirees. ${ }^{7} \quad$ It has been estimated that the 2000 reforms reduced benefits in aggregate by approximately $20 \%$ (Takayama, 2001).

Another aspect of the 2000 reforms was that they also altered future revenue streams. In particular, general revenues flowing into the NP were boosted, with the subsidy rising from one-third to one-half of the annual cost of the NP. Unlike the United States, where an earmarked payroll tax entirely finances the government old-age benefits at present, general revenue in Japan will be used to support even more of the total retirement system cost than before. There has been considerable debate over the most appropriate way to support these subsidies, with some analysts favoring consumption taxes, while others oppose them (Takayama, 2001; Hatta, 2001). The 2000 public pension reforms also hiked the maximum age for inclusion in the EPI program from 65 to 70 and extended covered earnings to include bonuses. Thus, future retirees will have substantially lower benefits that had previously been expected, even as they must pay higher taxes during their working years.

\footnotetext{
${ }^{7}$ The higher normal retirement age will be phased in over the next two decades. Persons born after April 2, 1961, will be eligible for full benefits for both the flat benefit and earnings related benefit at age 65 .
} 
As a result of these changes, the projected tax rate increase slated for the EPI was moderated; instead of doubling from $17.35 \%$ to $34.5 \%$, it is now expected to grow to $27.8 \%$ of covered earnings based on recent projections. ${ }^{8}$ Of course, this is still a substantial increase in payroll taxes required to support the social security system, and with the government subsidy, the total cost of the retirement system is larger still. Clearly Japan will continue to wrestle with the difficult issue of whether the public will agree to pay these higher taxes in the future, or whether it instead will reduce the public pension promise further (Clark and Ogawa, 1996).

\section{B. Japanese Company Pension Plans}

In the presence of these changes in the EPI and NP, employers and employees must consider how they want employer pensions to evolve. Should mandatory retirement ages be increased to match the new normal retirement ages in the EPI and NP? Should normal retirement ages for employer pensions also be increased? If social security benefits are being reduced, can employer pension benefits be expanded to keep retirement income at previous levels, or will current economic conditions mean that changes in employer pension plans will exacerbate the adverse effects of cuts in social security on retirement income? Given legislated changes in social security, the future of retirement income will be determined in large measure by how employer pensions are changed.

There are three main types of company retirement plans in Japan: unfunded severance benefit plans, the Employee Pension Funds (EPF), and the Tax Qualified Pension Plans (TQPP). More than 90\% of all Japanese employees have severance pay plans that relate termination benefits to years of service and earnings. These are financed from corporate operating revenue (they are book-reserved, for funding purposes). Severance benefits are typically paid as lump sums when workers leave their career employers. The average male retiree from a major corporation receives a severance payment of about $¥ 25$ million (US\$208,000) at retirement, equivalent to about 38 months of earnings (Seike, 1997).

\footnotetext{
${ }^{8}$ If the government were to try to adjust benefits to the level of revenue supplied by the current $17.35 \%$ payroll tax, we estimate that benefits would have to decline by more than one-third. This estimate is based on the simple calculation that if a specified benefit level requires $27.8 \%$ of covered earnings $(0.278$ times the wage base provides
} 
The average size of severance payments from a large corporation has increased over time (from $¥ 13$ million in 1974 , or US\$108,000 in today’s terms), but it has declined relative to annual earnings. Average monthly earnings rose 3.5 times between 1974 and 1996 (from $¥ 88,000$ to $¥ 305,000$; US\$733 to US\$2,542), while retirement payments less than doubled (Seike, 1997). One reason for this decline is the change in formulas used to determine severance pay and a reduction in the proportion of total compensation included in the determination of the benefit. Another reason is that the prevalence of severance plans is declining, as more firms shift from lump-sum payments to pension plans paying annuities. In 1974, 43\% of large companies had only lump-sum retirement plans and no additional pension plan. By 1996, only 5\% of all firms relied solely on the severance pay plans for retirement benefits (Seike, 1997).

Turning now to more conventional company pension plans, about half of all Japanese full-time employees participate in an EPF or a TQPP. There were 1,849 EPFs in 1999 covering over 12 million employees (Miyatake, 2000), a figure that represents 37\% of all EPI participants (Employees' Pension Fund Association, 1996). By contrast, there were more than 91,000 TQPP plans covering over 10 million workers. In the past, Japanese companies were allowed to offer only DB plans of these two types, but 2001 legislation has expanded options for plan choice.

EPF plans were introduced in 1966 to enable firms to provide earnings-related benefits to retired workers over and above the government earnings-related pension. They were established mainly by larger employers with 500 or more employees. ${ }^{9}$ These plans were permitted to partially "contract out" from paying contributions to the government pension system, in exchange for which they committed to provide benefits worth $130 \%$ of the EPI benefit. Historically, the EPFs have paid 3.2 to $3.8 \%$ of payroll to finance the contracted out component of the EPI (Employees' Pension Fund Association, 1996). EPF

sufficient revenues for an average benefit), then a tax rate of $17.35 \%$ of covered earnings would provide sufficient income for benefits that were $62 \%$ of the initial benefit level $(17.35 / 27.8=0.62)$.

${ }^{9}$ An individual company with at least 500 employees can establish an EPF. Allied companies can organize an EPF provided that they have 800 employees. Multi-company EPFs can be established provided that the plan sponsor has 3,000 participants. (Employees' Pension Fund Association, 1996). 
benefits based on the contracted-out or "substitutional" EPI component may be paid in the form of a life annuity, while supplemental benefits may be lump sum. Approximately $40 \%$ of beneficiaries opted to take a lump-sum distribution for the supplementary benefits in 1997 (Chunhong, 2000). EPFs have been regulated by the Ministry of Health, Labor, and Welfare, and have had to meet more reporting and funding standards than other types of Japanese pension plans.

TQPPs were first established in 1962, and they have been adopted by many small and mediumsize firms as well as some larger firms. Companies must have at least 15 employees to establish a TQPP. Most TQPPs are financed entirely from employer contributions, though in theory, employees are permitted to contribute to these plans. Despite their name ("tax qualified pension plans"), they are legally subject to an annual asset tax levied on the value of the pension portfolio, worth about $1.173 \%$ of assets. Most retirees under these plans can elect 10-year certain payouts, but most select a lump-sum option. The TQPPs have been supervised by the Ministry of Finance, historically, which has led to an entirely different set of regulations than those that govern the EPFs.

The growth of EPF pension plans in Japan has produced a DB plan asset pool (EPF plus TQPP) estimated at about US\$0.6 trillion, much smaller than the US private sector asset base (Sakamoto, 2001; Johnson, 2001). It must also be emphasized that any pension asset estimates are not directly comparable with those from other countries, since Japanese pension plans have traditionally marked assets at book value instead of market value; EPF assets have been marked to market only since 1997. Furthermore, Japanese asset values are currently quite depressed, and pension investment performance has been quite poor of late. The government suggested that pension investment returns be targeted at $5.5 \%$ annually and the Corporate Income Tax Law requires that the assumed ROR be at least 5\%; nevertheless, actual investment returns have been far lower. This is in part because of pension fund managerial conservatism, which is a legacy of the old regulatory 5:3:3:2 rule requiring that plans hold at least 50\% in secure assets such as long-term government bonds. These rules also limited other investments: caps were $30 \%$ on domestic stocks, $30 \%$ in foreign-currency assets, and $20 \%$ in real estate (Gordon, 1999). Recent evidence suggests that the EPF plans continue to allocate their portfolios in roughly this manner (Sekine, 2001). 
Limited evidence indicates that Japanese pensions are currently quite underfunded, at least according to Western standards. ${ }^{10}$ Chunhong (2000) and Goldman Sachs (1999) estimate that the total amount of underfunding in private corporate sector pension plans is between $¥ 40$ and 60 trillion (US\$404 to 485 billion). A 1996 study of 24 Japanese firms listed on the NYSE shows that pension assets were worth only $40 \%$ of liabilities (Gordon, 1999). According to data from the EPFA (Sakamoto 2001), half of all EPF plans in 1999 had less than $90 \%$ of the assets needed to cover liabilities, but these calculations do not adopt ERISA-type standards (Cerulli 2001). ${ }^{11}$ Severance pay plans tend to be not funded, and this liability represents yet another US\$324-404B (Goldman Sachs, 1999). Such extensive underfunding poses risks for existing DB plans, and it also makes the transition to new DB or DC plans more difficult.

\section{The Introduction of DC and New DB Plans in Japan}

Financialderegulation in Japan has been in full swing since the mid-1990s. The major impetus driving this effort was the desire to move toward a system where banks, insurers, securities firms, investment advisors, and foreign money managers would compete on a more level playing field (Cargill et al., 1997). For the first time, foreign money managers were permitted entry, companies began (slowly) to adopt international accounting standards, and insurance regulation was relaxed (Patrikis, 1998).

Accompanying this effort to modernize Japan's financial environment came a change in the rules governing employer-sponsored pensions. The changes were intended to make more flexible the heavily regulated system that previously "stifled creativity and short-changed the country's savers" (MacIntyre, 1998). Nevertheless this has been a gradual process. For instance, in 1999, the government eliminated the requirement that Employee Pension Funds liquidate their entire holdings when changing investment managers, and it further eliminated the practice of requiring fixed brokerage commissions on stock trades.

\footnotetext{
${ }^{10}$ Underfunding in the pension context refers to a gap between the pension plan assets and accrued liabilities. In the defined benefit context, under US private sector pension law, a plan would be underfunded if its assets valued at current market prices were less than the accumulated benefit obligation (ABO); see McGill et al. (1996).

${ }^{11}$ More specifically, $0.8 \%$ of EPF plans had assets that were less than $60 \%$ of liabilities, $8.8 \%$ of plans were between 60 and $70 \%, 21.6 \%$ of plans were between 70 and $80 \%, 19.8 \%$ were between 80 and $90 \%$, and $18.0 \%$ of all EPFs had funding between 90 and 100\% of assets (Sakamoto, 2001a).
} 
Subsequently, investment advisory firms were permitted to manage pension assets, whereas only trust banks and insurers had been allowed to do so previously. Life insurers gained entry to the mutual fund business, and the state-owned postal savings and life insurance bureaus (Yucho and Kampo) received permission to hire specialist investment managers to handle over $¥ 300$ trillion in postal saving system assets (US\$2.5 trillion; Asia Agenda International 2001). As Lincoln and Litan (1998) have noted, it was hoped that "by allowing Japanese pension funds greater investment freedom—specifically, broader authority to purchase equities, domestic and foreign — the Big Bang [would] help ease the pressure on Japanese corporations to fund their pension plans with current earnings."

\section{A. The Pension Reform Bill of 2001}

The Japanese government took a further step toward modernizing its pension sector in June of 2001 with legislation that alters plan design choices and aspects of existing plans (see Table 1). In many ways, this bill continues and extends the process of financial sector reforms implemented during the late 1990 s as they apply to pensions. ${ }^{12}$

\section{Table 1 here}

The pension reform bill contained features pertaining to both defined contribution (DC) and defined benefit (DB) plans. Focusing first on the DC set, the key elements were (William M. Mercer, 2001):

- Companies are permitted to offer DC pensions as of October of 2001.

- A corporate DC plan may be financed by tax-deductible employer contributions. (Employee contributions into such plans are not permitted.) If the plan sponsor has no other pension plan, annual tax-qualified DC contributions are capped at $¥ 432,000$ (US\$3,472); however if another tax-qualified plan is available, the taxable annual maximum DC contribution is reduced to $¥ 216,000$ (US\$1,736).

- A worker whose company offers no other pension may alternatively be offered a DC plan into which he can contribute out of pre-tax earnings up to an annual limit of $¥ 180,000$ (US\$1,447). No employer contributions are permitted in this case. The self-employed may set up DC plans into which they can contribute $¥ 816,000$ (US\$7,700).

- Employer DC plan contributions vest in three years and are portable if the worker changes companies.

\footnotetext{
${ }^{12}$ Cerulli $(1999,2000)$ has a useful discussion of the various players in the Japanese financial market and why they supported earlier versions of DC pension legislation in Japan.
} 
- Participants must be provided at least 3 investment choices for their DC monies, one of which must be principarguaranteed. Participants will be able to change investment allocations every three months.

- DC pension payouts may be taken as a lump sum or annuity as early as age 60 and payouts must commence by age 70 . A 60 -year old must have at least 10 years of participation; the service requirement falls to age 65 after which only one month of service is required.

- Companies must obtain employee permission before instituting a DC plan, and must obtain authorization from at least half of all employees before terminating an old DB plan and moving to a DC plan.

The pension reform bill of June 2001 also contained elements relevant to corporate sponsors of defined benefit plans (DB):

- Companies offering TQPP plans will be required to terminate them within a decade (Sakamoto, 2001a).

- Employers offering EPF plans will be permitted to divest themselves of the contracted-out "substitutional" element of their EPF plan (Sakamoto, 2001a). This will permit plan sponsors to gain relief from paying that portion of the government earnings-related pension by transferring a lump sum of assets to the government. However participants in the newly constituted DB plans will no longer be granted an exemption from the asset tax that had been imposed only on TQPP plans. The specific rules governing this restructuring of old EPF plans remain to be clarified. The Pension Fund Investment Fund will manage these assets and be responsible for paying the previously contracted out benefits (Cerulli 2001).

In addition to permitting new DC and DB plans, the 2001 law alters important aspects of the pension regulatory environment. ${ }^{13}$ The most evident change is that the new Ministry of Health, Labor, and Welfare (MHLW) will now supervise and regulate all DB plans as well as all new DC plans. In the past, the Ministry of Finance (MOF) had supervised TQPP plans; however now these plans must be terminated within ten years, and all new plans will be under the regulatory control of the MHLW. How these regulatory and supervisory tasks are to be managed at MHLW has not yet been clarified.

It appears that the severance pay plans mentioned above will be unaffected by this most recent pension law change; if so, they will remain book reserve and unfunded. However, the restructuring of pension plans in response to the 2001 legislation along with the continued evolution of other types of compensation may encourage firms to alter or eliminate their severance pay plans.

\footnotetext{
${ }^{13}$ The Financial Services Agency will supervise the function of financial institutions that are managing the assets of pension funds.
} 


\section{B. Defined Contribution Pensions in Japan: Unsettled Issues}

The new legislation on DC plans in Japan differs from that governing US 401(k) plans, which are DC pensions named after the section of the US tax code that established them. ${ }^{14}$ In evaluating the 2001 law changes, we have organized our comments about the emerging Japanese DC model according to the four main functions of a pension plan: collecting contributions, recordkeeping and reporting, managing investments, and paying benefits.

$\underline{\text { Issues pertaining to contributions and membership: }}$

\section{Which kinds of workers will be allowed to participate in the new DC plans?}

In practice, there may be administrative cost reasons to limit entry to workers under (or over) a cutoff age; or to restrict membership to new employees; or to limit participation to full-time workers. In the past, most part-time Japanese employees have not participated in company plans, leaving those workers with low coverage rates. ${ }^{15}$ Rules for DC plan participation in Japan are still being developed: whether these workers will now be included in company pensions, as the labor force becomes more flexible, will be interesting to watch. It is notable that Pasona, the first firm to adopt a DC pension plan in Japan, is a temporary employment agency that offers its part-time employees access to a portable pension program along with full-time workers. The 2001 regulations specify that the maximum age for employee participation in DC plans must be age 60.

2. Can the tax-qualified cap on employer contributions be increased, and will employees be allowed to contribute additional funds?

When pension reform legislation was being developed, many analysts and industry leaders expected that the level of tax-qualified contributions permitted in Japanese DC plans would be similar to those in the US 401(k) environment. However, the low employer contribution ceilings in the 2001 bill reflected the government's reluctance to allow more compensation to be protected from tax at a time

\footnotetext{
${ }^{14}$ For more on 401(k) plans in the US context see McGill et al. (1996).

${ }^{15}$ This is similar to the US where part-time employees have much lower pension coverage rates than full-time employees.
} 
when the economy was depressed and tax revenues were relatively low, producing fiscal deficits. The tax-qualified employer DC contributions under the new Japanese law are capped at an annual US\$3,472, about $6 \%$ of annual salary (Cerulli, 1999). ${ }^{16}$ Additionally, no matching employee contributions are permitted to these plans in Japan. By contrast, in the US, employee contributions to a 401(k) plan may total $\$ 10,500$ per year, a legal limit slated to rise to $\$ 15,000$ in 2006 . In addition, US employers can match employee contributions: the combined employer and employee DC contribution cap is now $\$ 35,000$, and it will rise to $\$ 40,000$ by 2006 (Portman and Cardin, 2001). New regulations allowing employee contributions in Japan would likely enhance the appeal of the DC model.

To help assess what a maximum contribution of about US\$3,500 might generate over work lives of various lengths for Japanese workers, we have prepared Table 2. This indicates the approximate accumulation value and an implied annuity payout of a DC plan over 10, 20, and 30 years of contributions. For example, after 30 years of investing the maximum contribution in a relatively safe asset such as might be permitted in the new Japanese DC environment, the worker could amass almost US\$122,000 (assuming a relatively conservative $1 \%$ real return). The annuity value of such an accumulation might be worth at most about US\$8,300 per year for men, or about $14 \%$ of current average earnings. ${ }^{17}$ The benefits are much smaller for shorter contribution periods: for instance after 10 years of saving, the annual payout would come to at most $\$ 2,500$ or about $4 \%$ of current average earnings.

\section{Table 2 here}

One factor that might make DC plan establishment more appealing in Japan is the possibility that companies could fund a new DC plan by contributing a tax-free lump sum recognizing workers' past service. It has been suggested that this would be equivalent to the annual maximum DC contribution level multiplied by each worker's years of service, plus a credit of the guaranteed rate of return promised by the

\footnotetext{
${ }^{16}$ A firm that offers another tax-qualified plan is limited to an employer maximum DC contribution of only US\$1,736 per year. A self-employed worker may contribute US\$7,700 to a tax-qualified plan, and an employee lacking any company plan may contribute up to US\$1,447 on a tax-qualified basis.

${ }^{17}$ This computation uses the Japanese EPF annuitant table and assumes no loads and no administrative costs; see McCarthy and Mitchell (2000).
} 
DB plan - traditionally 5.5\% (Cerulli 2001). While this might jump-start the formation DC plans, coming up with the lump sum might be difficult for firms that severely underfunded DB plans. A related issue is that the government has signaled a willingness to permit firms to terminate an old DB plan and move surplus assets into the new DC plan. We discuss this possibility below in more detail.

\section{Issues pertaining to record keeping:}

One lesson from the US market is that recordkeeping requires a substantial investment in information technology and a clean system of tracking individual participants (Mitchell 1998). While Japan has no system of unique taxpayer identification numbers, it has recently adopted a system of social security numbers to assist in the management of retirement accounts. In the past, the lack of unique identification numbers has made it difficult to both collect taxes and track employee accounts (Anderson, 1999). The fact that the new DC plans will be very small at the outset also exacerbates the start-up administrative and recordkeeping cost problems. If frequent fund transfers are permitted, this will also make it more costly to provide plan reporting and recordkeeping.

As a result, some have expressed concern that the likely small initial size of Japanese DC accounts will render the business unprofitable. For instance, Ruffel (2001) argues that "US experience shows that recordkeeping has proven in the main a distinctly unprofitable enterprise." Unless economies of scale and scope are perceived, this line of business in Japan will likely not prove very profitable in the short term. Thus Cerulli (1999) estimates that until DC accounts amount to at least US\$80 billion, recordkeepers will not break even. On the other hand, Sumitomo predicts that it will take only three years to cover start-up costs, and Fidelity has suggested that its expertise in the 401(k) market should help that firm arrive at break-even sooner (Anderson, 1999). $\underline{\text { Issues pertaining to investment management of DC plans: }}$

\section{Who will manage the money?}

There is substantial controversy about who will manage the money in the new Japanese DC framework. Some analysts estimate that $75 \%$ of new funds flowing into these plans will be principal guaranteed products (Anderson, 1999); others note that "(i)n the short term, there will be a preference for 
capital guaranteed-type products and that will favour in the short-term domestic players and not foreign players" (Johnson, 2001).

Additionally, Western experts suggest that DC plans require "a population willing to take advantage of newly available financial instruments. But the Japanese public remains distinctively risk averse in its investment decisions, keeping a high share of its savings in the form of bank accounts and insurance policies. It is not at all clear that many people will broaden their savings portfolios to include asset-backed securities, foreign mutual funds, derivatives, foreign bank accounts, and other investment opportunities. In the absence of an eager household sector, financial deregulation could leave the Japanese financial system under the continued domination of banks, which may end up as the primary holders of the new financial instruments" (Lincoln and Litan, 1998).

Based on the US experience, it would not be surprising if, during the early phases, DC plan participants tended to select fairly conservative investment holdings; on the other hand, they will be more likely to move to a better diversified portfolio, after learning more about the options. This process will be influence by the investment choices selected by plan sponsors, who select the types of options made available in their fiduciary role.

\section{How will investors be educated about risk and return?}

An interesting set of issues not yet settled in the changing Japanese pension environment is how plan sponsors and managers will handle a whole new set of responsibilities that heretofore they have not had to worry about. For example, plan sponsors must now ensure that contributions are actually invested, they must choose participant investment options; and they must as well as select and evaluate money managers. In the future, they will have to educate participants about risk and return. ${ }^{18}$ Eventually, they must see that benefits are paid. Some argue that DC plans are, in fact, "un-Japanese" and that it will be difficult to educate workers on how to manage their portfolios since they are not accustomed to taking

\footnotetext{
${ }^{18}$ Pension plans with individual accounts that require employees to make contribution and investment decisions necessitate that workers have a certain degree of financial literacy. Important issues for discussion include the extent of worker knowledge of financial markets, their understanding of the investment process, and the role of
} 
this responsibility. However, as one expert notes, "Japan has a math-literate population that will quickly grasp investment concepts...the empowerment of the individual could be surprisingly strong where they can participate in the market, and believe it to be a fair and well-regulated arena" (Global Custodian, 1998).

A related but not well-appreciated point is that the Japanese government is slowly altering its position on guaranteeing bank savings deposits. In particular, instead of providing a $100 \%$ guarantee as in the past, the government has indicated that only the first US\$85,000 of assets will be protected at some point in the future (this would amount to only 30\% of Japanese bank deposits; Anderson, 1999).

Eliminating the full guarantee for all benefits will not take place until mid-2003, but this change might powerfully alter DC plan participants' views of the principar guaranteed investment option mandated for the DC plan.

3. Will the new DC plans be subject to tax on inside buildup?

Japan has a tradition of exempting contributions into pension plans but taxing the asset value of the TQPP pension fund. The tax of $1.173 \%$ on the value of TQPP assets has been suspended until 2003, in view of the very low returns being earned by pension fund assets over the last decade. It is not known at present whether the suspension will be continued or the tax reimposed. Inevitably, imposition of such a high tax on Japanese pension funds that are invested in assets with extraordinarily low returns will discourage new pension formation.

Issues pertaining to payouts:

1. How will portability and vesting be handled?

At this juncture, little is known about how the new Japanese DC pension system will function in terms of vesting and portability. In the DC context, vesting refers to workers' claims on plan accumulations if they leave their employers prior to retirement. US employer contributions must be vested after 5 years, and the majority of $401(\mathrm{k})$ plans allow vesting earlier than that (one-third allow

companies in the provision of such education. These issues are also receiving considerable attention in the United States (Clark and d'Ambrosio, 2001). 
immediate vesting; Mitchell, forthcoming). Job-changing workers in the US are permitted to preserve their tax-qualified vested accumulations by moving the funds into either a new employer plan or into a "rollover" account handled by a licensed investment manager (McGill et al., 1996). The new regulations in Japan allow workers who change jobs to move all vested accumulations from one DC plan into another offered by the new employer. If the new employer does not offer a DC plan, the worker can leave the funds with the old employer's plan, or he may move them to the National Pension Fund Association. The new Japanese pension laws require that all employer contributions be vested after three years. While portability is specifically recognized in the regulations, the mechanism for exchanging pension assets across firms is as yet unclear.

\section{What about other types of payouts?}

In addition to rollover payouts, a set of rules must be written to govern pension payouts at retirement. It appears that the minimum age at which workers will be permitted to access the funds (known as the "preservation age" in some circles) will be 60 for the new Japanese DC plans. This is interesting since the national pension system's (NP) normal retirement age is slated to rise to 65 . The difference in the retirement ages under the two systems may create potentially unexpected incentives. As an illustration, retirees in Australia may access their entire DC accounts at 60 and spend down the entire amounts, prior to eligibility for a means-tested national benefit at 65 (Bateman et al., 2002). However, in Japan, some employers and older workers may anticipate that the company DC plan will support retirement consumption between age 60 and the age at which they are eligible to receive social security benefits.

This also illustrates the important interaction between the preservation age and how the funds can be accessed. In the US, many 401(k) plans provide lump sum payouts and only about one-quarter offer an annuity option (Mitchell, forthcoming). Allowing job changers to access their entire DC accumulations may undermine the plan's purpose as a retirement saving vehicle. An immediate spend-down is discouraged in the US; although 401(k) plan participants may receive their entire account in a lump sum if they wish, someone over age 70 must pay income tax on the entire lump sum, and a retiree younger 
than $591 / 2$ pays income tax as well as a $20 \%$ penalty on the sum. Another concern is that people may not buy inflation-indexed annuities with their DC accumulations, leaving them vulnerable to inflation and longevity risk (J. Brown et al., 2001).

\section{Defined Benefit Pensions in Japan: Unsettled Issues}

Just as several questions remain that, until they are clarified, will retard the development of DC plans in Japan, similar questions arise concerning the continued use of DB plans. These issues are organized according to the four main functions of a pension plan: collecting contributions, recordkeeping and reporting, managing investments, and paying benefits.

$\underline{\text { Issues pertaining to membership and contributions: }}$

\section{What types of plans will be permitted?}

Under the new pension law and regulations, there will clearly be a continued commitment to traditional DB plans in Japan, although many of these will now lack the contracting-out substitutional element previously found in the EPFs. There is also widespread belief that cash-balance or hybrid schemes will be allowed, although the method for establishment of such plans remains to be developed. Given the very low "safe" asset returns in Japan currently, it appears that hybrid plans could offer guaranteed rates of return only just over 1\% (Cerulli, 2001). The lower the guaranteed rate of return, the less appealing are cash balance plans. Unless foreign investment is pushed strongly as part of the funds portfolio, the low returns on domestic Japanese assets will make it more difficult to offer higher returns. Legally, hybrid plans will be DB plans, just as they are in the US (Feinberg 2001a).

\section{Who will establish these new DB plans?}

A company that previously sponsored a DB plan might consider moving to new DB plan depending on the type of plan it offered and its funding status:

- If a firm previously offered a TQPP plan, it must now terminate the plan within 10 years. As noted above, plan sponsors are typically smaller (15 employees and up), and they have tended to pay mainly lump sum benefits due to tax preferences. It appears that underfunding is a substantial problem in this sector, which may be a constraint if firms with TQPPs seek to set up new DB or DC plans.

- If a firm previously provided an EPF with the substitutional element, it may be entitled to buy out of the substitutional or contracted-out portion of the EPF plan by presenting the government with 
a satisfactory asset transfer to cover the buy-back. After this transfer is made, an EPF plan might or might not have sufficient assets to continue as a reformulated DB plan (without the contractedout portion), or to move toward a DC. Alternatively, the former-EPF plan may be allowed to amortize unfunded liabilities over a 20-year period after covering its obligation for the substitutional amount. Final regulations on these issues are still pending (Sakamoto, 2001b).

One key factor affecting the decision to offer a new DB plan is how the company's employees would react to the change. According to Japanese labor law, at least $50 \%$ of all employees must agree to convert a company pension from a DB to a DC. As an alternative, however, some firms have been allowed to terminate their old DB plan without obtaining the 50\% permission and have issued a lumpsum cash payout to discharge their old plan obligations. EPF plans can only be terminated with the approval of $75 \%$ of their trustees (Sakamoto, 2001b). At some future date, such companies may start up a new plan (DB or DC). In other words, a firm's plan choice under the new rules will be influenced by the extent of underfunding in its old DB plan as well as workers' agreement. If the plan has assets insufficient to cover the substitutional component of the EPF, it would be less likely to adopt a new plan.

A related issue is how the old EPF plan obligations are to be calculated when determining the assets sufficient to permit divestiture of the contracted-out portion. Regulations are still to appear regarding the buyout pric e for the EPF substitutional benefit. One approach might require valuing workers' and retirees' Accumulated Benefit Obligations (ABO) and setting aside assets sufficient to cover that portion of plan benefits. In this event, the choice of a discount rate becomes of paramount importance. Using a high rate shrinks future liabilities and makes it easier to set aside assets adequate to achieve the buy-back. Another possibility suggested by Japanese pension experts is that a firm might have to ante up a lump-sum equivalent to foregone contributions relative to the substitutional element in the EPF plan, plus very likely a low rate of return.

\section{Will employee contributions be permitted?}

The old EPF plans did permit employers and employees to share the financing of the substitutional component of the plan benefits. Similarly the TQPPs were permitted to have employee contributions, although in most cases, employers contributed the entire amounts (Conrad, 2001). It is not 
yet clear whether the new DB plans will be permitted to take employee contributions on a voluntary or mandatory basis.

4. Will the new DB plans be subject to tax on inside buildup?

As noted above, the $1.173 \%$ of assets tax on TQPP pensions is in suspension currently, but the plan is to reinstate the tax in 2003. Old DB plans may have little in the way of assets to tax. The asset tax may become important when the new DB plans amass some assets.

Issues pertaining to record keeping:

1. Will recordkeeping and reporting change for those employers remining with conventional DB plans alone?

According to available information, publicly-traded firms providing DB plans in Japan must move to implement international accounting standards. This will require recognizing pension liabilities using more realistic discount rates, and presumably will also lead to market valuation in measuring pension assets (Choy, 1999).

2. How will recordkeeping change if cash balance plans are permitted?

If cash balance or hybrid plans are accounted for as DB plans, as they are in the US, this will require the recordkeeping and reporting mentioned above, as well as the need to track and report on contributions made on individual workers' behalf, plus investment returns and individual accumulations. Issues pertaining to investment management of DB plans:

1. How might DB investment change?

As part of the Big Bang financial liberalization process, DB plan managers will no longer be required to assume that assets will return $5.5 \%$ per annum when projecting future pension costs. To the extent that plan sponsors do assume more realistic (and likely far lower) returns consistent with long-term Japanese patterns, this will reduce the chance that the newly-formed DB plans will become seriously underfunded. In addition, adopting modern investment strategies could also boost investment performance and enhance DB plan appeal, an avenue that institutional investors have already begun to explore. The Employees' Pension Fund Association in Tokyo, which oversees EPF pension management, 
recently introduced concepts of risk management to its member managers. Noboru Terada, a member of the Investment Expert Committee of the Government Pension Investment Fund, has expressed strong interest in indexing so as to hold down fees (Feinberg, 2001b). Terada has also pushed for a clearer statement of pension fiduciary responsibility, along the lines of the US ERISA law (Global Custodian, 1998).

\section{Will investment patterns become more diversified?}

To the extent that domestic asset returns remain depressed, it will remain difficult for DB plan sponsors to meet investment targets, and to avoid underfunding. For this reason DB plans are increasingly investing outside Japan. For instance, in 1998, Sony indicated that it would move a substantial component of its pension assets outside Japan in the hopes of reaping better rewards (Global Custodian, 1998).

Further, Honda Motor Co. has invested almost half its US\$4.6B pension fund outside Japan (MacDonald, 1998).

Issues pertaining to payouts:

How will annuities be handled?

When the EPFs were integrated with the government earnings-related pension, the plan sponsor was responsible for base nominal benefits but not for the inflation-indexation component of the EPI benefit. Whether the de-integration of DB plan benefits will alter this policy has not yet been clarified.

\section{Pension Plan Developments in the United States}

For the past 25 years, employer pension plans in the United States have been moving away from traditional defined benefit plans, toward defined contribution and various types of hybrid plans, especially cash balance plans. These developments have been in response to changes in government regulations that increased the cost of defined benefit plans, new tax policies that permitted pre-tax employee contributions to $401(\mathrm{k})$ plans, changes in the composition of the labor force, and fluctuations in the rate of economic growth. This section provides a brief history of the continuing evolution of occupational pensions in the United States. These developments and their causes can be compared to the current situation in Japan 
with the hope that analysis of US trends can provide some insights into the possible development of Japanese pension plans in the coming decade.

\section{A. Developments in US Defined Benefit Pensions}

Historically, pensions in the United States were primarily final pay, defined benefit plans that provided early retirement subsidies to many employees. These plans were especially prominent among large, unionized employers, and in the public sector. Since the mid-1970s, there has been a dramatic and continuing movement away from the use of DB plans and toward greater adoption of DC plans. More than $80 \%$ of pension participants were covered by a defined benefit plan in 1979, but by the mid-1990s, coverage by defined benefit plans had declined to only $50 \%$ of pension participants (PBGC, 1999). The rapid growth of DC plans is attributed to changes in government regulation that increased the cost of defined benefit plans relative to defined contribution plans, especially for small plans (Clark and McDermed, 1990). As a result, virtually no small employers now offer DB pensions. In addition, regulations permitting the development of $401(\mathrm{k})$ plans stimulated a rapid growth in these plans that allow pre-tax employer and employee contributions (Papke, 1999). Defined contribution plans tend to be more portable, and today's employees seem to place a greater emphasis on these individual account plans that can be taken with them when they change jobs.

In the last 15 years, some larger firms transformed their traditional DB plans into so-called "hybrid" or cash balance pensions. Legally these are classified as defined benefit pensions, but they have many characteristics of defined contribution plans. BankAmerica created the first hybrid pension in 1985. During the 1990s, the number of plan conversions increased, and by 2000, some 400 US companies had adopted a cash balance plan. Today, about $20 \%$ of the Fortune 500 firms offer cash balance plans (Cerulli, 2001).

Companies that establish cash balance pensions offer workers a mix of features taken from both DB and DC designs. Table 3 illustrates key features of DB and DC plans and compares them to cash balance provisions. Many contribution and participation features of a cash balance plan are similar to those of traditional DB plans, rather than to most DC plans, which allow employees to make decisions 
about participation and contribution rates. On the other hand, cash balance plans largely eliminate penalties for workers who terminate employment prior to retirement, which makes them similar to DC plans. The accumulation of accounts and provision of lump-sum benefits at termination facilitate communication and portability like 401(k) plans.

Table 3 here

Cash balance plans alleviate some but not all of the financial market risks faced by workers in self-directed DC plans. This is because a worker's account balance is credited with an annual rate of return equal to some specific rate such as the T-bill rate, sele cted usually by the employer. This reduces his exposure to investment risk in a DC plan. The plan sponsor does retain investment risk in cash balance plans, but the investment return promised workers is typically set so earnings on plan assets are anticipated to cover the guarantee. The worker still retains some residual investment risk in a cash balance plan, since benchmark rates used for crediting of returns to accounts will change over time. Nevertheless, the expectation would be that these will be le ss volatile than stock market returns. The participant also faces the risk that the plan sponsor might change the benchmark crediting rate over time.

Cash balance plans also have other differences from traditional DB pensions. One key feature is that they are more age -neutral than traditional DB plans in their retirement incentives. This arises because they tend not to have early retirement subsidies, as depicted in Figure 2. This illustrates the typical backloaded accrual pattern common to conventional DB pensions, and the much smoother accrual pattern pertinent to the typical cash balance plan. Another difference is that US cash balance plans must offer an annuity as a benefit option since they are legally DB plans; most also offer lump-sum benefits. Anecdotal evidence suggests that the overwhelming majority of workers takes lump-sum benefits when offered the choice under these plans.

Figure 2 here

\section{B. Changing Views on Retirement Plan Design}

A decade of US economic expansion, accompanied by a slower rate of growth in the labor force, has had a powerful impact on many companies' human resource policies. Previously, older workers were 
encouraged to retire so they could be replaced by lower-cost younger workers. More recently, employers have sought new methods to retain senior employees as hiring young workers became difficult. The composition of the labor force has also changed, prompting employers to accommodate the preferences of a more diverse and more mobile workforce.

These changes in the US labor market environment are manifested in changes in pension plan offerings and plan design. One development is that some firms have altered their DB plans to stop encouraging workers to retire in their 50s and early 60 s. Research shows that eliminating early retirement subsidies in a traditional DB plan greatly curtails retirement benefits for many employees, whereas converting to a cash balance plans can mitigate this benefit change (Clark and Schieber, 2001 forthcoming).

Another development is that companies are changing the entire structure and composition of employee compensation (K. Brown et al., 2000). Thus, converting a DB into a cash balance plan is also sometimes accompanied by changes in retiree health insurance provisions, or changes in contribution rates to supplemental retirement accounts. Companies have also reduced pension costs and then used cost-savings to offer more competitive non-pension compensation. Many US employers have focused on retaining productive senior employees, so that changes in pay and benefits reflect this new perspective.

A further explanation for the US trend to DC and cash balance plans is that workers often have difficulty understanding the value provided in DB plans. As a result, they may not value the expenses associated with traditional DB pensions (Clark and Munzenmaier, 2001). Financial concerns have also influenced employer decisions to shift from traditional DB to cash balance plans. This is because cash balance benefit accruals are smoother and more predictable throughout workers' careers, as compared to accruals in traditional DB plans. This sometimes stabilizes the stream of employer contributions needed to cover cash balance plans.

In some instances, US employees have argued that their employer may have used a cash balance conversion to limit or reduce the employer's expenditures on pension benefits. However, the evidence indicates that the results are more disparate. Some companies have lower costs after plan conversion, 
while others increase retirement expenditures; furthermore, many companies have essentially the same retirement costs before and afterward (K. Brown, et al., 2000). It has been claimed that some firms shifted to a cash balance plan when the traditional DB plans were overfunded. This conjecture is widely believed; however, the data show that many traditional DB plans that were not converted to cash balance plans were just as well-funded as those that were converted (Clark, Haley, and Schieber, 2001).

\section{Worker Preferences for Retirement Plan Type}

Limited evidence indicates that workers prefer some of the characteristics in Table 3 that hybrid plans share with defined contribution plans. Foremost among these is the element of individual accounts. It has been found that workers better understand having their own individual account balances, as compared to assessing the value of future benefits under a traditional DB plan (Clark and Munzenmaier, 2001; Third Millennium, 1999).

Another important feature of retirement plans with individual accounts is that the vested account balance is immediately available to a worker if he leaves the firm at any age. In other words, the current value of the pension is the same whether the worker remains with the firm or quits. In contrast, traditional DB plans tend to be backloaded, as discussed above, paying greater benefits to someone who remains with the firm until at least the age of early retirement. The portability feature of cash balance plans and DC plans is important to the increasingly diverse labor force in the US. Young workers in today's labor force are less likely to believe that they will work for the same firm for 30 or 40 years. Instead, expectations are that they will change jobs several times and as a result, they are more likely to demand retirement plans that have portable benefits.

\section{Implications for Japanese Pension Plans}

What implications might these US developments over the past three decades have for Japanese pension plans in the twenty-first century? What are the parallels that could lead to predictions about how Japanese plans will evolve? First, it seems clear that in the US, the emergence of defined contribution plans was driven, in part, by changes in regulations and tax policy. In the 1970s, the US government adopted regulatory policies that sharply increased the cost of defined benefit plans relative to defined 
contribution plans, especially among small firms. In addition, changes in tax laws in the 1980s allowed the development of new types of defined contribution plans based on employee contributions, the 401(k) plans. New changes in tax and regulatory policy may stimulate similar changes in Japan. However, as we have noted, the caps on employer contributions to defined contribution plans in Japan are much more restrictive than in the United States, and current regulations do not allow both employer and employee contributions to the same plans.

Second, changes in the composition of the US labor force have increased the demand for more portable pensions. Worker preferences for individual accounts, the option of lump-sum distributions based on accruals to date, less backloading of benefits, and easier to understand pension plans have also played a major role in the movement toward defined contribution and hybrid pension plans. As the Japanese system of industrial relations continues to evolve, these issues may become increasingly important to Japanese workers. In such a context, the growth of DC plans will proceed more rapidly. Third, the recent period of rapid US economic growth, in conjunction with a slowly growing labor force, has induced employers to develop human resource policies that retain older workers. Traditional DB plans embody important early retirement incentives, put in place during an era when employers were attempting to encourage early retirement. The Japanese labor force is also aging very rapidly, and the government is prodding companies to raise retirement ages. While the economic stagnation in Japan implies that companies are relatively uninterested in retaining older employees, the long-term demographic shift may stimulate modifications in pension policies along the lines seen in the US.

The importance of these factors in Japan will help determine the growth of DC and cash balance plans during the next decade. The US experience clearly illustrates that, under certain conditions, the transition from a system of mainly defined benefit pensions to one relying heavily on defined contribution plans can be quite rapid. 


\section{Discussion and Conclusions}

During the 2001 Japanese pension reform debate, plan sponsors, financial analysts, and many Japanese government officials indicated interest in reforming the nation's pension system. The 2001 legislation will surely spur the formation of new plans and the termination of some old ones. Despite the fact that a full set of regulations is not yet fully specified, some companies are already taking the initiative. Two large financial firms, Nomura Securities Co. and Nikko Securities Co., recently announced they will be withdrawing from their multi-employer DB association known as the Japan Securities Dealers Employees Pension Fund, to set up DC plans (Singer, 2001). This is consistent with Ruffell's view (2001) that many companies wish to relieve themselves of the old DB plans: “(t)he unfunded pension liabilities of corporate Japan defy measurement and they are growing daily—an awful domestic equity market, compounded by the truly woeful historic performance of the trust banks which manage the overwhelming bulk of institutional funds in Japan, has ensured that Japanese corporations have done nothing but contribute year after year into their defined benefit plans. For all the talk about Japan's societal need for defined benefit plans, an exodus of Japanese corporations fleeing a debilitating defined benefit framework for a less onerous defined contribution system can be taken as a given."

Plan redesign is taking place against the context of important, if slow, changes in the Japanese labor market. Large employers are less committed to and less able to guarantee lifetime employment, unemployment is rising, and pension benefits are changing along with the rest of compensation. In 1999, Nissan Motors laid off 21,000 workers in an attempt to cut costs. Some companie s, including Sumitomo Chemical, have even reduced retiree benefits; others curtailed prospective benefits by raising the retirement age from 60 to 65 (Anderson, 1999). These changes signal massive changes in the Japanese labor market, previously marked by lifetime employment and extraordinarily low levels of joblessness.

Even with the economic troubles plaguing Japan's macroeconomy, companies will still need to supply pensions, and employees will still demand pensions, for the same reasons they wanted them in the past. It also seems clear that as new accounting standards increase corporate and pension system transparency, Japanese firms will be increasingly interested in capping liabilities for pension benefits and 
severance pay. An alternative to reducing pension costs could be to flatten age/earnings profiles, and evidence suggests this is in fact starting to occur in Japan (Seike, 1997).

Informed opinion in Japan is extraordinarily divided regarding the likelihood of the DC plan model taking off in Japan. Some experts are very positive, arguing that the "scope of the DC market ... (is) between US\$193-770B" (Cornell 2001). By contrast, the US 401(k) market today amounts to over US\$2.3 trillion. Another positive view is Johnson's (2001), which suggests that the total pension asset pool to be created by the new pension law is larger still, at US\$777 billion. The bet here is that defined contribution assets will grow faster in Japan than current wisdom has it." Some 16\% of 128 listed Japanese firms surveyed indicated they were actively considering introducing a DC plan, and only $18 \%$ indicated they had no intention of changing their plan type (Dow Jones, 1999).

A less optimistic assessment comes from Cerulli, which projects the DC market at only US\$48 billion over the next five years (Anderson, 1999). In fact, this influential research group has stated that "DC plans remain the biggest mirage in the Japanese asset management industry" (Cerulli 2001), because of their low contribution ceiling and the persistent underfunding problem makes it difficult for firms to exit their DB plans. And of course the adoption of a DC plan, either solo or as a second-tier plan on top of a DB pension, will not alone solve the enormous underfunding problem associated with DB plans in Japan. As noted by Matsuura (2000), "the shift is likely to take several decades."

Some experts argue that instead of setting up DC plans, Japanese companies will move to cash balance plans because they are "better suited (than DC plans) for Japanese society... Many Japanese people like saving by using banks or the post office authority rather than investments such as bonds or equities, so many people will support cash balance plans (which don't require investment decisions by the employee) rather than DC plans" (Feinberg 2001a). Others concur, noting that: "cash balance plans are between DB and DC plans and look better suited to the beginners" (Feinberg, 2001a). In addition, experts estimate that they may offer a guaranteed rate of return below the 4-5\% currently assumed in DB plans, which should enhance their appeal to plan sponsors (Feinberg 2001a). 
On the surface, it may appear that the key factors that have spurred growth in the US cashbalance and DC arena over the last decade are not central to Japanese conditions today. Labor demand is far from robust; workers still do not change employers very frequently; traditional DB plans are underfunded; asset returns are low; and the new DC pensions do not have a particularly favorable tax environment. And as we have shown, many questions remain to be answered, particularly regarding the DC plan blueprint. Nevertheless, the fact that some major Japanese companies have already adopted DC plans presages greater momentum when the economy picks up again. If liberalized somewhat, the new pension models outlined by the 2001 legislation could provide Japanese savers an opportunity to diversify their investments so as to permit greater return with low risk. The recently enacted Japanese pension law will not turn all Japanese employer-sponsored pensions into 401(k)-style plans overnight, but it will make a contribution to modernizing the structure of Japanese compensation and retirement provision. In sum, the 2001 legislation could well signal the beginning of a "Big Bang" transformation in pay, benefits, and mobility for the Japanese labor market, and change Japanese workers from "savers" into "investors." 


\section{References:}

Anderson, Jenny. 1999. "Ready to Rumble”. Institutional Investor Online. November 1. http://www.iimagazine.com/channel/definedcontributions/199911010360.htm, viewed 8501.

Asia Agenda International. 2001. “Big Bang's Burning Pension Fuse”. Japan Pensions Industry Database. http://www.asiagenda.com/timer.htmviewed 8401.

Bateman, Hazel, Geoffrey Kingston, John Piggott. 2002. Forced Saving: Mandating Private Retirement Income. Cambridge University Press: Cambridge.

Brown, Kyle, Gordon Goodfellow, Tomeka Hill, Richard Joss, Richard Luss, Lex Miller, and Sylvester Schieber. 2000. The Unfolding of a Predictable Surprise. Bethesda, MD: Watson Wyatt Worldwide.

Brown, Jeffrey, Olivia S. Mitchell, James Poterba, and Mark Warshawsky. 2001. The Role of Annuity Markets in Financing Retirement. MIT Press: Cambridge, MA.

Cargill, Thomas, Michael Hutchison and Takatoshi Ito. 1997. “Japan’s ‘Big Bang’ Financial Deregulation: Implications for Regulatory and Supervisory Policy:” Japan Information Access Project, June. http://www.nmjc.org/jiap/dereg/papers/deregcon/hutchison.html, viewed 8401 .

Cerulli Associates. 1999. Trends in the Japanese Asset Management Marketplace. The Cerulli Report. Cerulli Associates, Inc. Boston, MA.

Cerulli Associates. 2001. Japanese Asset Management. The Cerulli Report. Cerulli Associates, Inc. Boston, MA.

Choy, John. 1999. “Japan Securities Industry: From Big Bang to E-Boom”. Japan Economic Institute Report. $22 \mathrm{~A}$. June 11.

Chunhong, Chan. 2000. “An Overview of Japan Pension System and Pension Reform.” Tokyo: NLI Research Institute, unpublished paper.

Clark, Robert. 1991. Retirement Systems in Japan. Homewood, IL: Irwin (Pension Research Council).

Clark, Robert and Madeleine d'Ambrosio. 2001. "Financial Education and Retirement Savings" unpublished paper, North Carolina State University.

Clark, Robert, John Haley, and Sylvester Schieber. 2001. “Adopting Hybrid Pension Plans: Financial and Communication Issues,” Benefits Quarterly 17(1): 7-18.

Clark, Robert and Ann McDermed. 1990. The Choice of a Pension Plan in a Changing Regulatory Environment. Washington: American Enterprise Institute.

Clark, Robert and Fred Munzenmaier. 2001. "Impact of Replacing a Defined Benefit Pension with a Defined Contribution Plan or a Cash Balance Plan,” North American Actuarial Journal, Fourth Quarter, 9(4): 6-14.

Clark, Robert and Naohiro Ogawa. 1996. "Public Attitudes and Concerns about Population Aging in Japan," Ageing and Society 14(4): 190-208.

Clark, Robert and Sylvester Schieber. 2001 forthcoming. "Taking the Subsidy Out of Early Retirement: The Story Behind the Conversion to Hybrid Pensions," in Olivia Mitchell, Zvi Bodie, Brett Hammond, and Steve Zeldes (eds.), Innovations in Managing the Financial Risks of Retirement. Philadelphia: University of Pennsylvania Press.

Conrad, Harald. 2001. The Japanese Social Security System in Transition: An Evaluation of Current Pension Reforms. Tokyo: German Institute for Japanese Studies. 
Cornell, Andrew. nd. “Japan Opens Up \$3Tn Pensions Market.” Financial Review. http://afr.com/handheld/2001/067/27/FFXH2FWAFOC.html viewed 8401.

Dow Jones. 1999. “Japan Companies Seen Favoring DC Pensions”. Dow Jones News Wire. New York April 28.

Employees' Pension Fund Association. 1996. Pension Schemes in Japan. Tokyo: Pension Fund Association.

Feinberg, Phillis. 2001. "Japan Prepares for Dawn of its Cash Balance Era". Pensions and Investments, July 9: 1. [2001a]

Feinberg, Phyllis. 2001. "Risk Budgeting, Indexing Catch on in Japan". Pensions and Investments, June 25: 14. [2001b]

Foreign Press Center. 2001. "Defined Contribution Pension Plan to Begin in October.” Japan Brief, FPC 0128, Embassy Newsletter. http://www.embjapan.dk/info/Japan\%20Brief\%etc2001/jb250601.htm. viewed 8401.

Global Custodian. 1998. "In Perry’s Wake”. Spring. http://www.assetpub.com/gcspring98/perry right.html viewed 8501

Goldman Sachs. 1999. "Unfunded Liabilities of Japanese Corporate Pensions”. Pension Group Services Report. May 20.

Gordon, Bill. 1999. "A Critical Evaluation of Japanese Accounting Changes Since 1997”. University of Sheffield dissertation for Masters in Advanced Japanese Studies. http://wgordon.web.wesleyan.edu/papers.jacc2.htm viewed 8501 .

Hatta, Tatsuo. 2001. Personal Communication with the authors. Tokyo, July.

Japan Institute of Labor, 2000. Japanese Working Life Profile: 2000 Labor Statistics. Tokyo.

Johnson, Simon. 2001. "Hard Run for Japan’s Pension Money.” Financial Review. June 27. http://afr.com/personalfinance/2001/06/27/FFX3AEXAFOC.htmviewed 8401.

Lincoln, Edward J. and Robert E. Litan. 1998. "The "Big Bang"? An Ambivalent Japan Deregulates Its Financial Markets." Brookings Review. Winter 1998 Vol. 16 No. 1: 37-40 http://www.brook.edu/press/review/win98/linwi98.htm viewed 8401.

MacDonald, James. 1998. “Japan's Pension Funds Hike Foreign Investing: Managers Gear Up for Accounts." Pensions and Investments, November 16:16.

MacIntyre, Donald. 1998. "Bang, You're Liberalized: Japan's big move to free its financial markets is marred by a wave of bad news and investor jitters." Time Magazine. April 13, 1998151 (14): http://www.time.com/time/magazine/1998/int/980413/japan.html, viewed 8401.

Matsuura, Tamie. 2000. "The Tax Treatment of the DC Plan, from Company and Individual Perspectives.” NLI Research. no. 138, June.

McCarthy, David and Olivia S. Mitchell. "Assessing the Impact of Mortality Assumptions on Annuity Valuation". Pension Research Council Working Paper, Wharton School, 2000.

McGill, Dan, Kyle N. Brown, John J. Haley, Sylvester J. Schieber. 1996. Fundamentals of Private Pensions. 7e. Pension Research Council. University of Pennsylvania Press. 
Ministry of Health, Labor, and Welfare. 1999. Outline of Social Insurance in Japan. Tokyo: Ministry of Health, Labor, and Welfare.

Mitchell, Olivia S. 1998. “Administrative Costs of Public and Private Pension Plans”. In Privatizing Social Security, Ed. Martin Feldstein. NBER. Chicago: University of Chicago Press: 403-456.

Mitchell, Olivia S. 2001. "Managing Pensions in the Twenty-First Century: Global Lessons and Implications for Japan." Presented at the 1999 CIRJE Conference on Social Security Reform in Advanced Countries, University of Tokyo. Revised.

Mitchell, Olivia S. forthcoming. "New Trends in Pension Benefit and Retirement Provisions". In Benefits for the New Workplace. Eds. O.S. Mitchell, D. Blitzstein, M. Gordon, and J. Mazo. University of Pennsylvania, Pension Research Council.

Miyatake, Go. 2000. Social Security in Japan. Tokyo: Foreign Press Center.

Ogawa, Naohiro. 2001. Personal communications with the authors.

Papke, Leslie. 1999. "Are 401(k) Plans Replacing other Employer-Provided Pensions?: Evidence from Panel Data," Journal of Human Resources. 34(2): 346-368.

Pasona, Inc. "Pasona Launches 401kNet Internet Finance Site with To-Shin Shijo" http://www.pasona.co.jp/english/jeu/03.html viewed 8501.

Patrikis, Ernest.1998. “Japan’s Big Bang Financial Reforms.” First Vice President, Federal Reserve Bank of New York. Speech at the Brooklyn Law School, April 27. http://www.ny.frb.org/pihome/news/speeches/ep980427.html, viewed 8401.

Pension Benefit Guaranty Corporation. 1999. Pension Insurance Data Book, 1998. Washington: PBGC.

Portman, Rob and Ben Cardin. 2001. The Comprehensive Retirement Security and Pension Reform Act( HR 10), http://www.house.gov/portman/pensiondetailed.htm viewed 8401.

Ruffell, Charles. 2001. "DC in Japan: The Sun Might Be Setting on the Skeptics.” Plan Sponsor. June 21. http://www.plansponsor.com/eprise/main/PlanSponor/News/Opinions/carjapan401k viewed 8401.

Sakamoto, Junichi. 2000. "Pension Reform and Funding Options". Paper presented at the $13^{\text {th }}$ International Conference of Social Security Actuaries and Statisticians, Quebec October.

Sakamoto, Junichi. 2001a. Personal communication with authors, Tokyo, July.

Sakamoto, Junichi. 2001b. Personal communication with authors, e-mail, August.

Seike, Atsushi. 1997. New Trends in Japan's Labor Market. Tokyo: Foreign Press Center.

Sekine, Kenji. 2001. Personal communication with authors, email, August.

Singer, Jason. 2001. "Nikko, Like Nomura, To Exit Pension Fund”. Asian Wall St. Journal. July 16:1.

Takayama, Noriyuki. 2001. "Reform of Public and Private Pensions in Japan." Paper presented to Ninth Annual Colloquium of Superannuation Researchers, The University of New South Wales, Sydney, Australia.

Third Millennium. 1999. Public Attitudes Toward Cash Balance Retirement Plans. 
William M. Mercer, Inc. 2001. "Defined Contribution Plan Legislation Passed in Diet", Global Market Alert. Late Breaking Information for Multinational Employers. June 28.

http://www.wmmercer.com/global/english/resource_news_market_topic_01_09_htm. viewed 8401. 
Table 1. The Japanese Retirement Provision System: Old and New Structures

The Pre-2001 Environment

Non-Earnings Related Publicly-Run Retirement Plan

National Pension Insurance (NPI):

20 million self-employed members ("type 1 persons");

39 million private sector employees, civil servants, etc (type 2 members).

12 million insured dependents ("type 3 members");

Earnings-Related Employer-Sponsored Partly Private, Partly Public Pension Plans

Employee Pension Insurance (EPI):

33 million members; covers all "type 2" members in private sector.

Employee Pension Plans (EPF):

12 million members; substitute for some EPI benefits and contributions

Tax Qualified Pension Plans (TQPP):

10 million members

Lump Sum Severance Pay Plans:

Covers $80 \%$ of enterprises (Japan Institute of Labor, 2000)

Mutual Aid Associations:

6 million members, set up separately from EPI benefits and contributions (certain sectors).

Personal Provision

Personal Pension Plans

Private Saving and Family Support

Source: Derived from Conrad (2001)

Changes Under 2001 Reforms

Tier 1: Non-Earnings Related Publicly-Run Retirement Plan

National Pension Scheme (NP): no change

Tier 2: Earnings-Related Employer-Sponsored Partly Private, Partly Public Pension Plans Employee Pension Insurance (EPI): No change

Employee Pension Plans (EPF): Firms with DB may buy out of substitutional EPI component; new DC plans as well as DB plans to be permitted, possibly cash balance plans;

Tax Qualified Pension Plans (TQPP): to be phased out over 10 years

Mutual Aid Associations: No change.

Tier 3: Personal Provision

New Individual Pension to be permitted

Personal Pension Plans: No change

Private Saving and Family Support: No change

Source: Derived from Sakamoto (2001) 
Table 2. Estimated Real Value of Japanese DC Account Accumulation and Annual Benefit if Annuitized

\begin{tabular}{cccc} 
Years of & Retirement & \multicolumn{2}{c}{ Annuitized Single } \\
Life Value \\
Saving & Accumulation & Men & Women \\
\hline \hline 10 & $\$ 36,618$ & $\$ 2,497$ & $\$ 1,904$ \\
20 & $\$ 77,067$ & $\$ 5,255$ & $\$ 4,008$ \\
30 & $\$ 121,747$ & $\$ 8,301$ & $\$ 6,331$
\end{tabular}

Source: Authors' computations.

Notes: Assumes maximum contribution of US $\$ 3,500$ (real) per year; $1 \%$ real rate of return on assets pre and post retirement; no mortality prior to retirement; no investment fees or insurance loading; single-life annuity; and EPF (sex-specific) tables after retirement at age 65. 
Table 3: Features of US Employer-Sponsored Retirement Plans

\begin{tabular}{|c|c|c|c|c|}
\hline Plan feature & $\begin{array}{c}\text { Defined } \\
\text { Benefit plan }\end{array}$ & $\begin{array}{c}\text { Defined } \\
\text { Contribution plan } \\
\end{array}$ & $\begin{array}{c}\text { Cash } \\
\text { Balance plan } \\
\end{array}$ & $\begin{array}{c}\text { Cash Balance } \\
\text { Tendency }\end{array}$ \\
\hline $\begin{array}{l}\text { Employer } \\
\text { contributes }\end{array}$ & Virtually always & Sometimes & $\begin{array}{l}\text { Virtually } \\
\text { always }\end{array}$ & DB \\
\hline $\begin{array}{l}\text { Employee } \\
\text { contributes }\end{array}$ & Very rarely & Virtually always & Very rarely & DB \\
\hline Participation & Automatic & Employee choice & Automatic & DB \\
\hline Contribution level & Automatic & Employee choice & Automatic & DB \\
\hline PBGC Insurance & Yes but capped & Not needed & Yes but capped & DB \\
\hline $\begin{array}{l}\text { Early departure } \\
\text { penalty }\end{array}$ & Yes & No & No & DC \\
\hline $\begin{array}{l}\text { Benefits easily } \\
\text { portable }\end{array}$ & No & Yes & Yes & DC \\
\hline $\begin{array}{l}\text { Annual } \\
\text { communication }\end{array}$ & $\begin{array}{l}\text { Benefit at end of } \\
\text { career }\end{array}$ & Current balance & Current balance & $\mathrm{DC}$ \\
\hline $\begin{array}{l}\text { Retirement } \\
\text { incentives }\end{array}$ & $\begin{array}{c}\text { Occur at specific } \\
\text { ages }\end{array}$ & Neutral & $\begin{array}{c}\text { Most are } \\
\text { neutral }\end{array}$ & DC \\
\hline $\begin{array}{l}\text { Accrual of } \\
\text { benefits }\end{array}$ & $\begin{array}{l}\text { Loaded to career } \\
\text { end }\end{array}$ & Level over career & $\begin{array}{l}\text { Level or back } \\
\text { loaded }\end{array}$ & Mixed \\
\hline $\begin{array}{l}\text { Financial market } \\
\text { risks }\end{array}$ & Employer bears & Employee bears & Shared & Mixed \\
\hline $\begin{array}{l}\text { Longevity } \\
\text { insurance }\end{array}$ & Typically yes & Typically no & Not often taken & Mixed \\
\hline
\end{tabular}

Source: Clark, Haley, and Schieber (2001) 
Figure 1. Schematic View of Japanese Retirement Programs Pre -2001 (number of members)

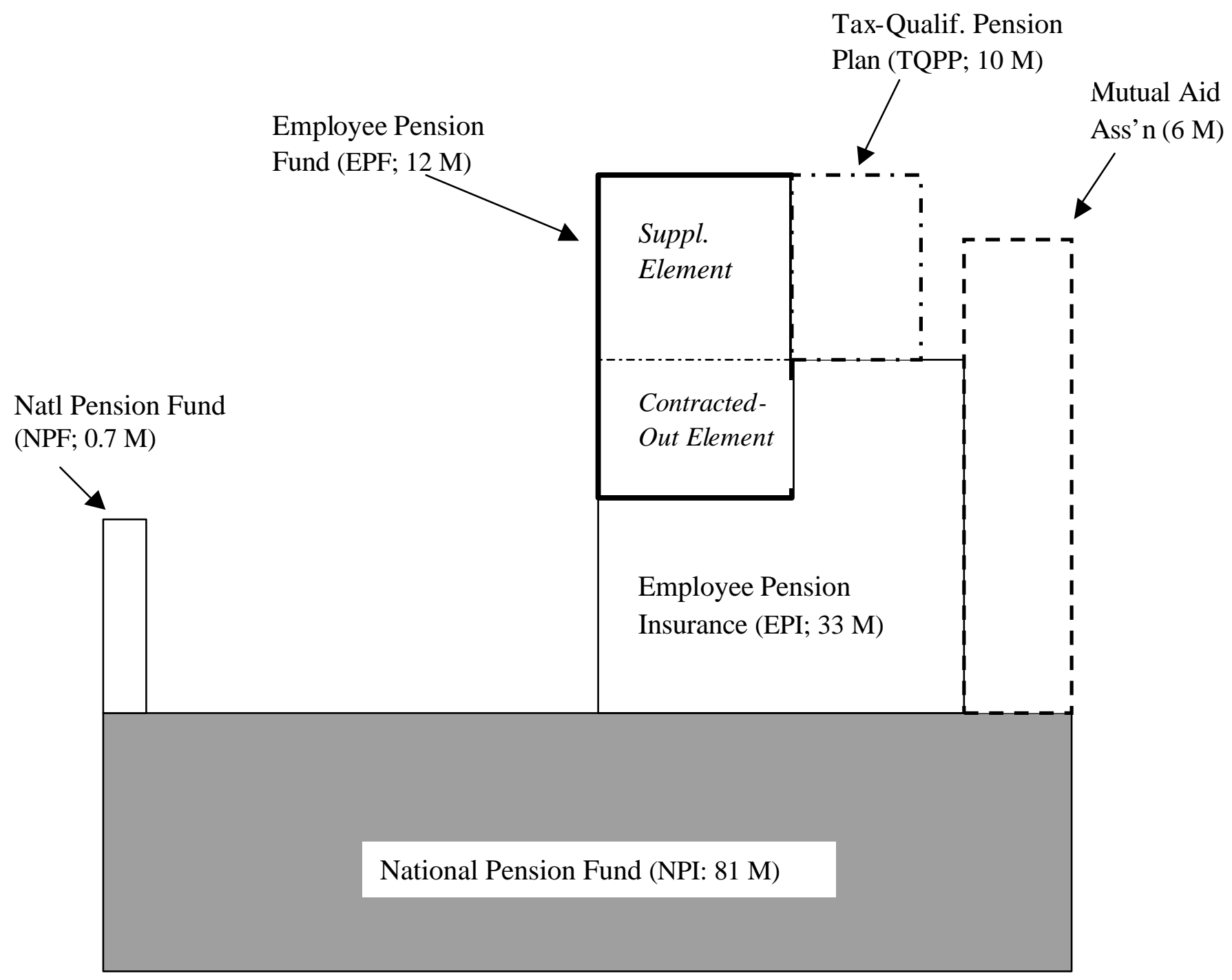

Source: Derived from Conrad (2001) and Sakamoto (2001) 
Figure 2: Value of Accrued Pension Benefit as a Multiple of Annual Wage at Various Ages for a New Hire at Age 30 with a Starting Wage of $\$ 40,000$ per Year
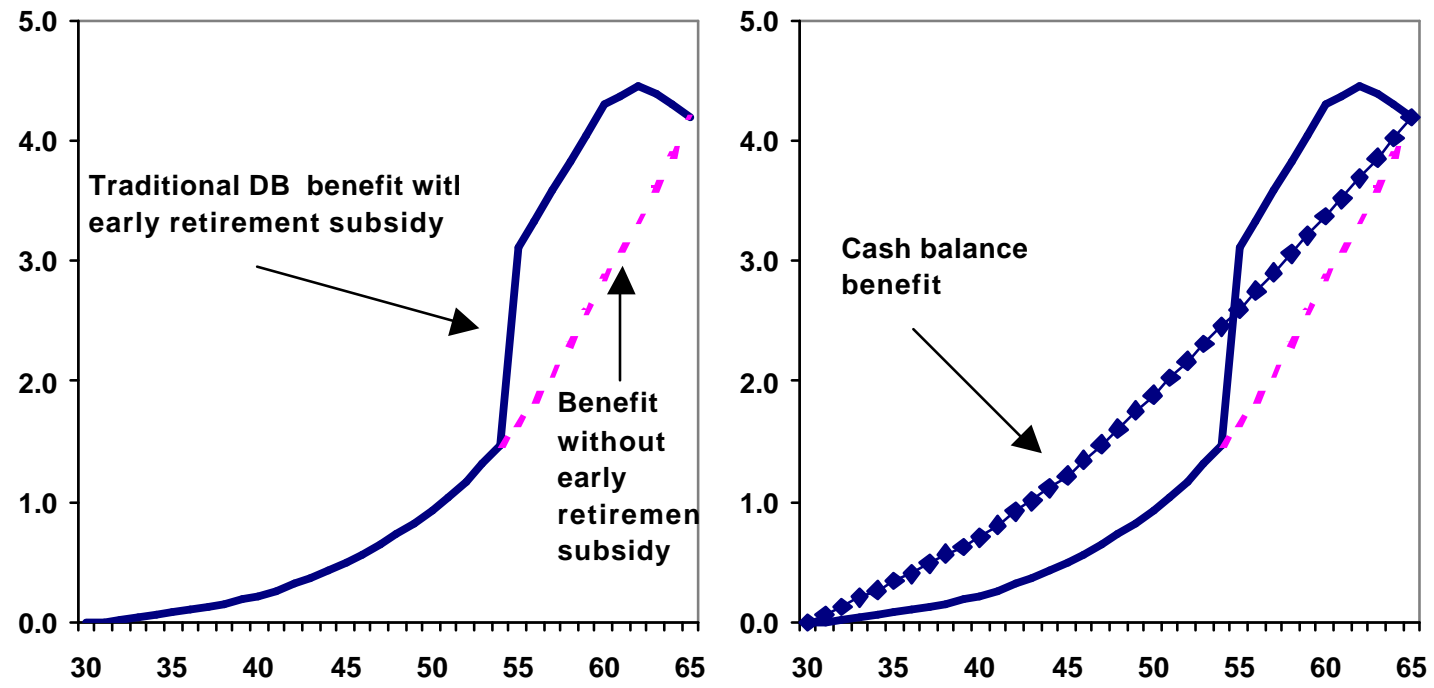

Source: Clark and Schieber (2001 forthcoming). 